\title{
Subcutaneous adiposity is an independent predictor of mortality in cancer patients
}

\author{
Maryam Ebadi ${ }^{1}$, Lisa Martin ${ }^{1}$, Sunita Ghosh ${ }^{2}$, Catherine J Field ${ }^{1}$, Richard Lehner ${ }^{3}$, \\ Vickie E Baracos ${ }^{2}$ and Vera C Mazurak ${ }^{*}, 1$ \\ ${ }^{1}$ Division of Human Nutrition, Department of Agricultural, Food and Nutritional Science, University of Alberta, Edmonton AB T6G \\ 2E1, Canada; ${ }^{2}$ Department of Oncology, University of Alberta, Cross Cancer Institute, 11560 University Avenue, Edmonton T6G \\ 1Z2, Canada and ${ }^{3}$ Department of Pediatrics, Group on Molecular and Cell Biology of Lipids, University of Alberta, 328 Heritage \\ Medical Research Centre, Edmonton T6G 2R3, Canada
}

Background: Prognostic significance of adiposity, at the time of cancer diagnosis, on survival is not clear. Body mass index $\left(\mathrm{kg} \mathrm{m}^{-2}\right)$ does not provide an appropriate assessment of body composition; therefore, the concept of the 'obesity paradox' needs to be investigated based on the prognostic significance of fat and muscle. Independent prognostic significance of adipose tissue in predicting mortality, importance of visceral and subcutaneous adiposity in the presence and absence of sarcopenia on survival, was investigated.

Methods: Adiposity markers including total adipose index (TATI), visceral adipose tissue index (VATI) and subcutaneous adipose tissue index (SATI) were estimated for 1473 gastrointestinal and respiratory cancer patients and 273 metastatic renal cell carcinoma patients using computed tomography. Univariate and multivariate analysis to determine mortality hazard ratios (HR) were conducted using cox proportional hazard models.

Results: Low SATI (SATI $<50.0 \mathrm{~cm}^{2} \mathrm{~m}^{-2}$ in males and $<42.0 \mathrm{~cm}^{2} \mathrm{~m}^{-2}$ in females) independently associated with increased mortality (HR: 1.26; 95\% Cl: 1.11-1.43; $\mathrm{P}<0.001)$ and shorter survival (13.1 months; $95 \% \mathrm{Cl}$, 11.4-14.7) compared to patients with high SATI (19.3 months; 95\% Cl, 17.6-21.0; $P<0.001)$. In the presence of sarcopenia, the longest survival was observed in patients with high subcutaneous adiposity.

Conclusions: Subcutaneous adipose tissues appear to associate with reduction in mortality risk demonstrating the prognostic importance of fat distribution. The effect of sarcopenia on survival was more pronounced in patients with low subcutaneous adiposity.

Fat loss has emerged as a poor prognostic factor in patients with advanced cancer independent of body weight (Murphy et al, 2010). However, the prognostic significance of adiposity, at the time of cancer diagnosis is not clear. The 'obesity paradox' refers to obese patients experiencing longer survival after a diagnosis of a disease and has been described in some wasting associated diseases such as cancer, cardiovascular disease, diabetes, and renal diseases (reviewed by Prado et al, 2015). While some studies have shown an association between obesity and poor survival
(Meyerhardt et al, 2003; Dignam et al, 2006; Doria-Rose et al, 2006; Kasenda et al, 2014), others have reported obesity, compared to low or healthy body mass index (BMI, $\mathrm{kg} \mathrm{m}^{-2}$ ), to be associated with lower mortality after a cancer diagnosis (Hakimi et al, 2013; Hughes, 2013; Martin et al, 2013; Schlesinger et al, 2014). Previous studies addressing the obesity paradox have primarily used BMI as an assessment of body composition. BMI does not provide an appropriate assessment of body composition as it does not differentiate between fat and fat-free mass or

*Correspondence: Dr VC Mazurak; E-mail: vmazurak@ualberta.ca

Received 30 November 2016; revised 4 April 2017; accepted 2 May 2017; published online 6 June 2017

(C) 2017 Cancer Research UK. All rights reserved 0007 - 0920/17 
different fat depots. Adipose tissue and skeletal muscle are two major body compartments with different functions; therefore, the concept of the 'obesity paradox' needs to be investigated based on the independent prognostic significance of fat and muscle rather than the BMI. Moreover, individual variability in adiposity (Noori et al, 2010), especially visceral adiposity (Kuk et al, 2005; Kaneko et al, 2015) exists within each BMI category. Recently studies have applied computed tomography (CT) imaging to deal with the controversial concept of the obesity paradox. CT image analysis is an opportunistic method for body composition evaluation in an oncological population, due to CT imaging being a component of standard care (Ebadi and Mazurak, 2014). CT image analysis enables precise quantification of adipose depots and muscle and has emerged as the gold standard for body composition assessment in cancer patients (Fabbro et al, 2010). Visceral and subcutaneous adipose differ in anatomic location, endocrine function, adipokine secretion and lipolytic activity (reviewed previously (Wajchenberg, 2000; Ibrahim, 2010)). Variability in regional adipose tissue distribution by sex (Wajchenberg, 2000) and within each category of BMI (Kuk et al, 2005; Kaneko et al, 2015), as well as divergent behavior of adipose depots (Wajchenberg, 2000; Ebadi et al, 2016) demonstrates the need to understand the importance of visceral and subcutaneous adiposity in cancer survival.

Recently, Martin et al (2013) reported that BMI $\geqslant 25 \mathrm{~kg} \mathrm{~m}^{-2}$ in both sexes was associated with longer survival using sexspecific cutoffs in a large cohort of cancer patients. However, survival advantage of obesity was diminished in the presence of concurrent conditions including weight loss, sarcopenia (low muscle mass) and low muscle radiodensity (fat infiltrated muscle). Considering BMI limitations in predicting adiposity, sex-specific values associated with mortality for adipose tissue are required to evaluate the effect of low muscle mass on survival of high adiposity patients.

Studies assessing the effect of adiposity, either visceral or subcutaneous, on cancer survival have yielded inconsistent results (Rickles et al, 2013; Fujiwara et al, 2015; Kaneko et al, 2015; Lee et al, 2015). Small sample sizes, lack of cancer-specific cut offs associated with survival, exclusion of conventional or body composition variables associated with survival in multivariate analysis as well as focusing on short- or long-term mortality as an outcome contribute to inconsistent results. Previous studies have applied cut-offs derived from renal cell carcinoma patients in an Asian population (Kaneko et al, 2015; Lee et al, 2015) that may not be generalizable to all cancer populations or to non-Asians. Moreover, adipose tissue distribution differs by sex (Wajchenberg, 2000), which demonstrates the need to apply sex-specific cut offs.

Considering the limitations of using BMI as an indicator of adiposity, an adiposity index is preferred. However, controversy remains regarding prognostic significance of adipose tissue in cancer, as adiposity cut-points associated with survival in cancer are unknown. The majority of previously published studies have used median or sex specific median to evaluate the association of adiposity with survival. However, sex-specific values that associate with survival are required. Lack of cut-offs characterise a major gap in the understanding of the relationship between adiposity and risk of death after a cancer diagnosis. We aimed to explore the independent prognostic significance of adipose tissue as well as the importance of visceral and subcutaneous adiposity in estimating cancer mortality in a large cohort of cancer patients. Survival advantage of adiposity in the presence and absence of sarcopenia was also evaluated. It was hypothesised that higher adiposity, especially subcutaneous adiposity, as defined by CT images would be associated with the lowest mortality risk in cancer patients, but that the presence of sarcopenia would diminish the survival advantage of high adiposity.

\section{MATERIALS AND METHODS}

Patients. The study was performed in accordance with the institutional research ethics board. Alberta Cancer Board Research Ethics Board (Edmonton, Alberta, Canada) reviewed and approved this study. Our site encompasses patients in Northern Alberta, Canada. Data regarding cancer site, morphology, clinical and demographic characteristics for each of the subjects were collected from the Alberta Cancer Registry. We extracted data from gastrointestinal or respiratory cancer patients' initial visit to medical oncology before receiving any treatment, between January 2004 and January $2007(n=1473)$. Patient's baseline characteristics for gastrointestinal and respiratory tract cancers were reported in detail in Martin et al (2013). CT scans for this study were taken within 30 days of patient's initial assessment. Metastatic renal cell carcinoma patients $(n=273)$ treated with sunitinib between March 2005 and 2012 at the Cross Cancer Institute (Edmonton, Alberta, Canada) were also included in this study. For these patients, CTs within a median of 26 days (95\% CI: 12-63 days) from the start of the treatment were used to represent baseline body composition. Selfreported height, weight and performance status (PS) were collected using the Patient-Generated Subjective Global Assessment.

CT image analysis. All participants had body composition measured using secondary analysis of images retrieved from the patient clinical record. Total adipose tissue area measurement was conducted by analyzing CT scans at the third lumbar vertebra (L3). The third lumbar was selected as a standardised landmark, as adipose tissue areas in a single CT image at L3 correlate well with whole body fat mass (Shen et al, 2004a; Mourtzakis et al, 2008). Regression equations for visceral adipose tissue have not been developed for cancer populations; however, visceral adipose tissue cross-sectional area at L3 strongly correlate with whole-body visceral adipose tissue volume in healthy populations (Shen et al, 2004b). Two consecutive transverse CT images extending from L3 to the iliac crest were assessed using Slice-O-Matic (V4.2; Tomovision, Montreal, QC, Canada). Adipose tissue cross-sectional areas were calculated by using standard Hounsfield Unit (HU) thresholds of -29 to $150 \mathrm{HU}$ for skeletal muscle (SM), -150 to $-50 \mathrm{HU}$ for visceral adipose tissue (Miller et al, 1998) and -190 to $-30 \mathrm{HU}$ for subcutaneous adipose tissue (Mitsiopoulos et al, 1998). Tissue cross-sectional areas $\left(\mathrm{cm}^{2}\right)$ were calculated by summing the given tissue pixels and multiplying by the pixel surface area. Mean tissue areas for two consecutive images were calculated; the mean $\mathrm{CV}$ of paired images was $2.7 \%$ for adipose tissue areas. Visceral and subcutaneous adipose tissues cross-sectional areas were summed to estimate total adipose tissue areas. The cross-sectional areas of skeletal muscle, total adipose tissue, visceral adipose tissue and subcutaneous adipose tissue were normalised for the patient height to calculate indexes $\left(\mathrm{cm}^{2} \mathrm{~m}^{-2}\right)$ for skeletal muscle (SMI), total adipose tissue (TATI), visceral adipose tissue (VATI) and subcutaneous adipose tissue (SATI). Mean muscle radiation attenuation (HU) was reported as muscle radiodensity which correlates with triglyceride content of the muscle (Aubrey et al, 2014).

Statistical analysis. Descriptive statistics are presented as mean \pm s.d. for continuous variables and percentage for categorical variables. The comparison between study groups were conducted using independent $t$-test and Pearson $\chi^{2}$ test for continuous and categorical variables, respectively. Overall survival was defined as the time from diagnosis to the date of death or date of last contact of August 2010 for 1473 gastrointestinal and respiratory tract cancer patients. For 273 
metastatic renal cell carcinoma patients, time from the start of sunitinib treatment to the date of death or date of last contact (March 2012) were defined as survival time. Patients alive at the time of the last contact were censored at the date last known to be alive. Univariate and multivariate analysis to determine mortality hazard ratios (HR) were conducted using Cox proportional hazard models to identify significant predictors of mortality. Variables significant at $P<0.10$ level in the univariate analysis were selected to be entered in the multivariate model. Results were reported as HRs and 95\% confidence intervals (CIs). Factors known to correlate with mortality of cancer patients (Martin et al, 2013) including age, sex, cancer type, stage, performance status as well as body composition variables including lumbar skeletal muscle index, muscle radiodensity and TATI or VATI and SATI were included in the analysis.

Cut-off values for lumbar skeletal muscle index (SMI) and muscle radiodensity were derived from Martin et al (2013) established cut-offs in gastrointestinal and respiratory cancer patients (Martin et al, 2013). For SMI, values below $41 \mathrm{~cm}^{2} \mathrm{~m}^{-2}$ in females of all BMI categories and SMI values below $43 \mathrm{~cm}^{2} \mathrm{~m}^{-2}$ in males with a BMI $<25$ and SMI $<53 \mathrm{~cm}^{2} \mathrm{~m}^{-2}$ in male with a $\mathrm{BMI} \geqslant 25$ associated with shorter survival and were considered as sarcopenic groups. Muscle radiodensity of $<33 \mathrm{HU}$ in patients with a BMI $\geqslant 25$ and $<41$ in those with a BMI $<25$ associated with shorter survival (Martin et al, 2013).

Sex-specific adiposity values associated with the lowest mortality risk were determined by examining the continuous variable on the basis of quartiles using the first quartile as the reference group in an adjusted multivariate model. Following, adjunct quartiles with similar risk of death (non-statistically significant different HRs indicated by non-significant $P$-value in Cox model) were pooled together and statistically significant values that provide satisfactory discrimination of mortality risk between patients were determined for each sex. High adiposity, characterised by TATI $\geqslant 107.7 \mathrm{~cm}^{2} \mathrm{~m}^{-2}$ in male and $\geqslant 102.2 \mathrm{~cm}^{2} \mathrm{~m}^{-2}$ in females, were the values that associated with the lowest mortality risk (Supplementary Tables S1A and S1B). In order to find mortality associated values, VATI and SATI were separately divided into quartiles and in adjusted models, visceral adiposity of VATI of $52.9 \mathrm{~cm}^{2} \mathrm{~m}^{-2}$ in males and $51.5 \mathrm{~cm}^{2} \mathrm{~m}^{-2}$ in females were defined as VATI values that discriminate between high and low risk patients. SATI $\geqslant 50 \mathrm{~cm}^{2} \mathrm{~m}^{-2}$ in males and $\geqslant 42 \mathrm{~cm}^{2} \mathrm{~m}^{-2}$ in females, defined as high subcutaneous adiposity, were set as values associated with the lowest mortality. Following men and women were pooled together and using sex-specific values, the independent prognostic significant of adiposity were evaluated in whole population.

Kaplan-Meier curves were plotted to estimate survival over time and the log-rank test were used to compare the difference between high vs low adiposity survival curves. Pearson correlation test was conducted to assess whether there was a significant relationship between adiposity and muscle radiodensity. Analyses were performed using IBM SPSS Statistic Software 21 (SPSS for Windows, version 21.0, SPSS, Chicago, IL, USA). $P$-values $<0.05$ was considered as a significant difference.

\section{RESULTS}

Patient characteristics are summarised in Table 1. The most common cancer was colorectal (42\% of cancer types in both sexes) with the majority of patients in stage IV (62\% in men and 59\% in women). Patients were followed until death $(n=1207)$ or censoring (the date last known to be alive; $n=555$ ). The median overall survival of the cohort was estimated to be 16.7 months (95\% CI, 15.4-18.1) and the median follow-up of censored patients
Table 1. Patient characteristics by sex at baseline

\begin{tabular}{|c|c|c|c|}
\hline & $\begin{array}{c}\text { Male } \\
(n=1047)\end{array}$ & $\begin{array}{c}\text { Female } \\
(n=715)\end{array}$ & \\
\hline Characteristics & $n(\%)$ & $n(\%)$ & $P$ \\
\hline $\begin{array}{l}\text { Age, years } \\
\text { Mean } \pm \text { s.d. }\end{array}$ & $64.4 \pm 11.0$ & $64.6 \pm 11.3$ & $0.8^{\mathrm{a}}$ \\
\hline $\begin{array}{l}\text { Cancer site } \\
\text { Colon/rectum } \\
\text { Respiratory tract } \\
\text { Pancreas } \\
\text { Esophageal } \\
\text { Stomach } \\
\text { Other Gl } \\
\text { Kidney }\end{array}$ & $\begin{array}{c}439(42) \\
229(22) \\
69(7) \\
16(1) \\
33(3) \\
18(2) \\
243(23)\end{array}$ & $\begin{aligned} & 301(42) \\
& 207(29) \\
& 75(10) \\
& 7(1) \\
& 18(3) \\
& 19(3) \\
& 88(12)\end{aligned}$ & $<0.001^{b}$ \\
\hline $\begin{array}{l}\text { Cancer stage } \\
\text { I } \\
\| \\
\text { III } \\
\text { IV }\end{array}$ & $\begin{array}{c}35(3) \\
134(13) \\
224(21) \\
654(63)\end{array}$ & $\begin{array}{r}35(5) \\
88(12) \\
169(24) \\
423(59)\end{array}$ & $0.22^{b}$ \\
\hline $\begin{array}{l}\text { ECOG PS } \\
0 \\
1 \\
2 \\
3 \\
4\end{array}$ & $\begin{array}{l}201(19) \\
468(45) \\
207(20) \\
158(15) \\
13(1)\end{array}$ & $\begin{array}{l}139(19) \\
313(44) \\
133(19) \\
115(16) \\
14(2)\end{array}$ & $0.72^{b}$ \\
\hline BMI, $\mathrm{kg} \mathrm{m}^{-2}$ & $26.3 \pm 4.7$ & $25.3 \pm 5.9$ & $<0.001^{a}$ \\
\hline $\begin{array}{l}\text { BMl category, } \mathrm{kg} \mathrm{m}^{-2} \\
\quad<20.0 \\
20.0-24.9 \\
25.0-29.9 \\
\geqslant 30.0\end{array}$ & $\begin{array}{c}72(7) \\
356(35) \\
406(39) \\
195(19)\end{array}$ & $\begin{array}{l}124(18) \\
263(37) \\
184(26) \\
134(19)\end{array}$ & $<0.001^{b}$ \\
\hline $\begin{array}{l}\text { Skeletal muscle index, } \\
\mathrm{cm}^{2} \mathrm{~m}^{-2}\end{array}$ & $51.4 \pm 8.7$ & $41.1 \pm 7.0$ & $<0.001^{a}$ \\
\hline Muscle radiodensity, HU & $34.7 \pm 9.0$ & $34.0 \pm 10.2$ & $0.12^{\mathrm{a}}$ \\
\hline $\begin{array}{l}\text { Total adipose index, } \\
\mathrm{cm}^{2} \mathrm{~m}^{-2}\end{array}$ & $111.3 \pm 59.1$ & $112.6 \pm 72.7$ & $0.69^{\mathrm{a}}$ \\
\hline $\begin{array}{l}\text { Visceral adipose index, } \\
\mathrm{cm}^{2} \mathrm{~m}^{-2}\end{array}$ & $57.0 \pm 36.4$ & $34.6 \pm 27.6$ & $<0.001^{a}$ \\
\hline $\begin{array}{l}\text { Subcutaneous adipose } \\
\text { index, } \mathrm{cm}^{2} \mathrm{~m}^{-2}\end{array}$ & $54.3 \pm 29.7$ & $77.9 \pm 50.3$ & $<0.001^{a}$ \\
\hline \multicolumn{4}{|c|}{$\begin{array}{l}\text { Abbreviations: } \mathrm{BMI}=\text { body mass index; } \mathrm{ECOG} P \mathrm{PS}=\text { Eastern Cooperative Oncology Group } \\
\text { performance status; } \mathrm{Gl}=\text { gastrointestinal; } \mathrm{HU}=\text { Hounsfield unit; s.d. }=\text { standard deviation. } \\
\text { Continuous variables are presented as mean } \pm \text { s.d. } \\
\text { a Independent } t \text {-test for continuous variables. } \\
\text { b }_{\text {Pearson }} \chi^{2} \text { test for categorical variables comparison. }\end{array}$} \\
\hline
\end{tabular}

was 24.8 months (95\% CI, 20.8-28.8). Fifty-three percent of the population were overweight or obese. Men had higher BMI and SMI than women (Table 1). Although TATI did not differ between males and females, fat distribution differed between sexes, with men having greater visceral adiposity and women having more subcutaneous fat (Table 1).

To evaluate the independent prognostic significance of adiposity in predicting mortality, an adjusted Cox proportional hazard analysis was performed. The following variables associated with mortality risk in patients: age, cancer type, stage, PS, TATI, SMI and muscle radiodensity in the univariate analysis (Table 2). Compared with the reference group with high adiposity, patients with low adiposity, had a significant increase in mortality risk after adjustment for major predictors of survival (HR: 1.26; 95\% CI: $1.11-1.41 ; P<0.001)$ (Table 2). Patients with high adiposity survived 19.8 months (95\% CI, 17.6-22) while the median survival in low adiposity group was 14.0 months (95\% CI, 12.4-15.6) $(P=0.001)$.

In order to investigate the importance of fat depots in predicting cancer mortality, in the next step, multivariate analysis was repeated including all of the same variables presented in 
Table 2. Median survival, univariate and multivariate analysis by conventional and body composition parameters for overall mortality

\begin{tabular}{|c|c|c|c|c|c|c|c|}
\hline Characteristics & No. of patients & No. of deaths & Median $(95 \% \mathrm{Cl})$ & \multicolumn{2}{|c|}{ Univariate } & \multicolumn{2}{|c|}{ Multivariate } \\
\hline $\begin{array}{l}\text { Sex } \\
\text { Female } \\
\text { Male }\end{array}$ & $\begin{array}{r}715 \\
1047\end{array}$ & $\begin{array}{l}482 \\
725\end{array}$ & $\begin{array}{l}15.6(13.7-17.5) \\
17.2(15.3-19.0)\end{array}$ & $1.10(0.95-1.20)$ & 0.27 & & \\
\hline Age, years & & & & $1.01(1.00-1.01)$ & $<0.001$ & $1.008(1.002-1.01)$ & 0.01 \\
\hline $\begin{array}{l}\text { Cancer site } \\
\text { Colon/rectum } \\
\text { Respiratory tract } \\
\text { Pancreas } \\
\text { Esophageal } \\
\text { Stomach } \\
\text { Other Gl } \\
\text { Kidney }\end{array}$ & $\begin{array}{r}740 \\
436 \\
144 \\
23 \\
51 \\
37 \\
331\end{array}$ & $\begin{array}{r}358 \\
383 \\
126 \\
16 \\
41 \\
23 \\
260\end{array}$ & $\begin{aligned} 30.7 & (27.5-33.9) \\
9.4 & (7.7-11.2) \\
5.4 & (3.8-7.0) \\
17.5 & (9.6-25.5) \\
11.3 & (6.7-16.0) \\
20.6 & (3.4-37.8) \\
17.7 & (14.4-21.0)\end{aligned}$ & $\begin{array}{l}2.83(2.44-3.27) \\
3.94(3.21-4.84) \\
1.93(1.17-3.18) \\
2.46(1.78-3.40) \\
1.59(1.04-2.42) \\
1.54(1.31-1.81)\end{array}$ & $\begin{array}{c}<0.001 \\
<0.001 \\
<0.001 \\
<0.001 \\
0.03 \\
<0.001\end{array}$ & $\begin{array}{l}2.59(2.23-3.01) \\
3.16(2.58-3.93) \\
1.80(1.09-2.98) \\
2.20(1.59-3.05) \\
1.46(0.96-2.23) \\
0.83(0.69-1.00)\end{array}$ & $\begin{array}{c}<0.001 \\
<0.001 \\
0.02 \\
<0.001 \\
0.08 \\
0.05\end{array}$ \\
\hline $\begin{array}{l}\text { Cancer stage } \\
\text { I } \\
\text { II } \\
\text { III } \\
\text { IV }\end{array}$ & $\begin{array}{r}70 \\
222 \\
393 \\
1077\end{array}$ & $\begin{array}{r}21 \\
61 \\
209 \\
916\end{array}$ & $\begin{array}{l}37.2(22.2-52.3) \\
52.4(42.2-62.6) \\
29.0(23.6-34.4) \\
10.3(9.1-11.4)\end{array}$ & $\begin{array}{r}0.76(0.46-1.25) \\
1.3(0.83-2.03) \\
2.9(1.88-4.47)\end{array}$ & $\begin{aligned} & 0.29 \\
& 0.25 \\
&< 0.001\end{aligned}$ & $\begin{array}{l}1.03(0.62-1.69) \\
1.42(0.90-2.23) \\
3.85(2.48-5.97)\end{array}$ & $\begin{aligned} & 0.92 \\
& 0.13 \\
&< 0.001\end{aligned}$ \\
\hline $\begin{array}{l}\text { TATI } \\
\text { High } \\
\text { Low }\end{array}$ & $\begin{array}{l}881 \\
881\end{array}$ & $\begin{array}{l}572 \\
635\end{array}$ & $\begin{array}{l}19.8(17.6-22.0) \\
14.0(12.4-15.6)\end{array}$ & $1.26(1.11-1.41)$ & $<0.001$ & $1.26(1.12-1.41)$ & $<0.001$ \\
\hline $\begin{array}{l}\text { SMI } \\
\text { Non-sarcopenic } \\
\text { Sarcopenic }\end{array}$ & $\begin{array}{l}998 \\
746\end{array}$ & $\begin{array}{l}652 \\
539\end{array}$ & $\begin{array}{l}19.6(17.6-21.7) \\
14.0(12.4-15.6)\end{array}$ & $1.25(1.12-1.40)$ & $<0.001$ & $1.01(0.9-1.14)$ & 0.86 \\
\hline $\begin{array}{l}\text { Muscle radiodensity } \\
\text { High } \\
\text { Low }\end{array}$ & $\begin{array}{l}746 \\
998\end{array}$ & $\begin{array}{l}444 \\
738\end{array}$ & $\begin{array}{l}20.4(17.5-23.3) \\
13.7(12.1-15.3)\end{array}$ & $1.41(1.25-1.59)$ & $<0.001$ & $1.33(1.17-1.51)$ & $<0.001$ \\
\hline
\end{tabular}

Table 3. Median survival and mortality hazard ratios $(95 \% \mathrm{Cl})$ for (a) visceral and subcutaneous adiposity and for (b) 4 -adiposity phenotypes in fully adjusted models

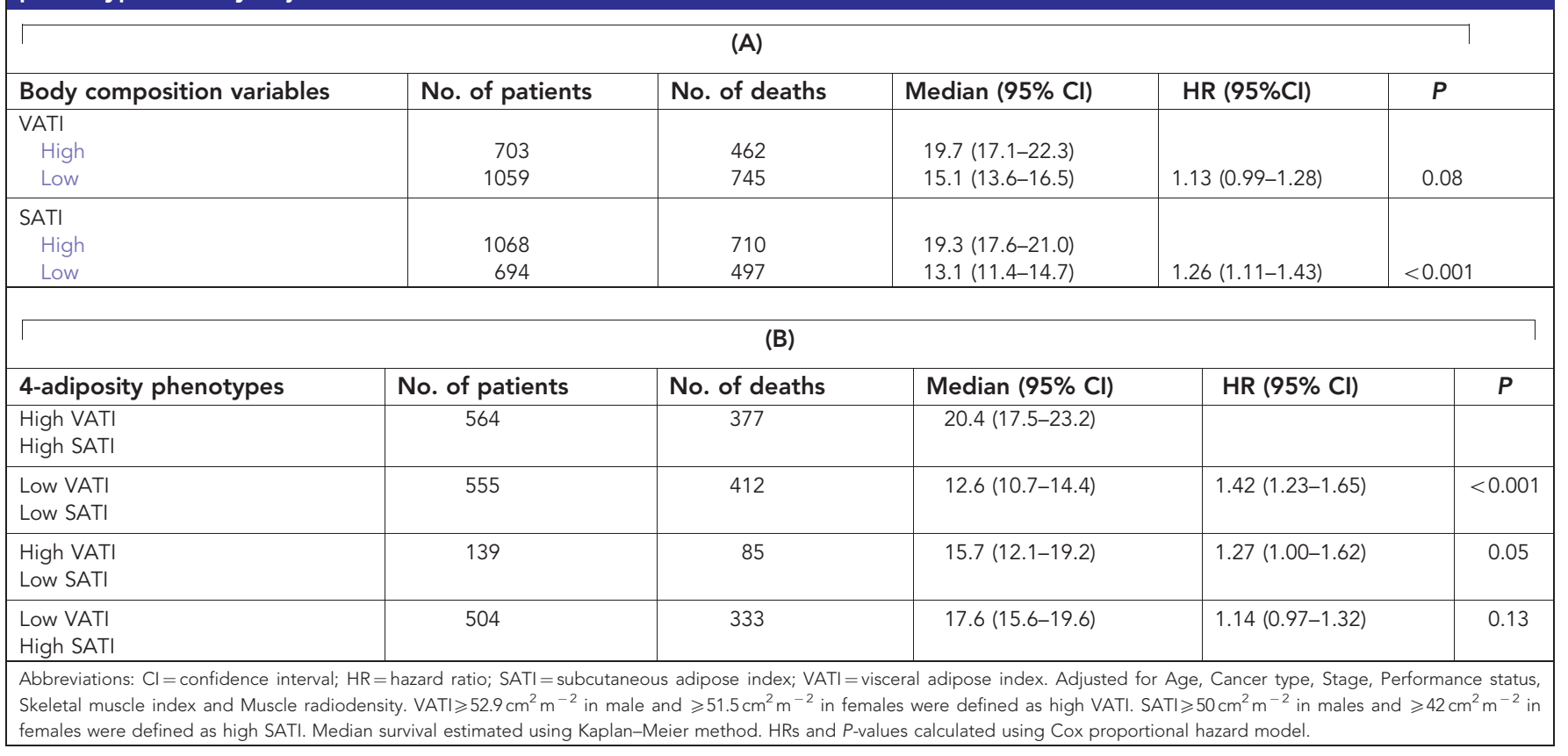




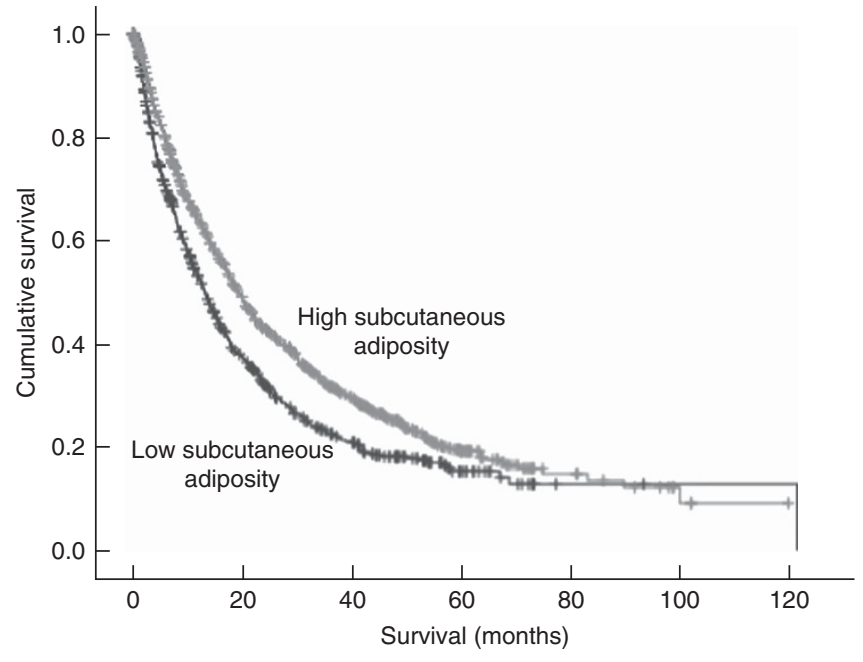

Figure 1. Kaplan-meier survival curves in patients with high vs low subcutaneous adiposity. Kaplan-Meier curves were plotted to estimate survival over time and the log-rank test were used to compare the difference between survival curves. Longer median survival was observed in patients with high subcutaneous adiposity compared to the patients with low subcutaneous adiposity $(P<0.001)$.

Table 2 and VATI and SATI rather than TATI. In multivariate analysis, including both VATI and SATI, only subcutaneous adiposity significantly associated with survival (Table $3 \mathrm{~A}$ ). Compared to the high SATI group, low SATI was an independent predictor of increased mortality in multivariate analysis (HR: 1.26; 95\% CI: 1.11-1.43; $P<0.001$ ) (Table 3A). Subsequently, we used a Kaplan-Meier model to estimate survival probability based on subcutaneous adiposity, revealing longer median survival in patients with high SATI (19.3 months; 95\% CI, 17.6-21.0) compared to the patients with low SATI (13.1 months; 95\% CI, 11.4-14.7) (Figure 1; $P<0.001$ ). The trend for high VATI patients to have a longer median survival time (19.7 months; $95 \%$ CI, 17.1-22.3) compared to those with a lower VATI (15.1 months; 95\% CI, 13.6-16.5) was not significant (Table 3A; $P=0.08)$.

To investigate the prognostic significance of different depots, patients were categorised into one of four phenotypes according to categories of high and low VATI and SATI (Table 3B). Having low SATI was associated with the shortest survival with the highest mortality risk. Patients with both high SATI and VATI had the best survival advantage with a median survival of 20.4 months (Table 3B). Therefore, the diminished survival in patients with high visceral adiposity concurrent with low subcutaneous adiposity suggests high visceral adiposity may not be protective alone and indicates the importance of high subcutaneous adiposity.

Low subcutaneous adiposity was more prevalent in male patients with low BMI (Table 4). No significant difference was observed between low and high SATI patients regarding cancer stage and performance status. Mean SMI was significantly higher in those with greater subcutaneous adiposity $\left(48.1 \pm 10 \mathrm{~cm}^{2} \mathrm{~m}^{-2}\right)$ compared to the low SATI group $\left(45.8 \pm 8.6 \mathrm{~cm}^{2} \mathrm{~m}^{-2}, P<0.001\right)$ (Table 4). Despite having higher SMI, patients with high subcutaneous adiposity had significantly lower muscle radiodensity compared to the patients with low SATI $(31.6 \pm 9.2$ vs $38.7 \pm 8.4$, $P<0.001$ ) (Table 4). Among patients with high subcutaneous adiposity, $62 \%$ exhibited low muscle radiodensity. The association between adiposity and muscle radiodensity was investigated and a moderate, but highly significant, inverse association was observed between the muscle radiodensity, and visceral adipose adiposity

\begin{tabular}{|c|c|c|c|}
\hline & $\begin{array}{l}\text { Low } \\
\text { subcutaneous } \\
\text { adiposity } \\
(n=694)\end{array}$ & $\begin{array}{c}\text { High } \\
\text { subcutaneous } \\
\text { adiposity } \\
(n=1068)\end{array}$ & $P$ \\
\hline $\begin{array}{l}\text { Sex, n (\%) } \\
\text { Male } \\
\text { Female }\end{array}$ & $\begin{array}{l}516(74) \\
178(26)\end{array}$ & $\begin{array}{l}531(50) \\
537(50)\end{array}$ & $<0.001^{\mathrm{a}}$ \\
\hline Age, years & $64 \pm 12$ & $64 \pm 11$ & $0.68^{b}$ \\
\hline $\begin{array}{l}\text { Cancer site, } n \text { (\%) } \\
\text { Colon/rectum } \\
\text { Respiratory tract } \\
\text { Pancreas } \\
\text { Esophageal } \\
\text { Stomach } \\
\text { Other Gl } \\
\text { Kidney }\end{array}$ & $\begin{array}{c}296(43) \\
187(27) \\
70(10) \\
14(2) \\
29(4) \\
12(2) \\
86(12)\end{array}$ & $\begin{array}{c}444(42) \\
249(23) \\
74(7) \\
9(1) \\
22(2) \\
25(2) \\
245(23)\end{array}$ & $<0.001^{a}$ \\
\hline $\begin{array}{l}\text { Cancer stage, } n \text { (\%) } \\
\text { I } \\
\text { II } \\
\text { III } \\
\text { IV }\end{array}$ & $\begin{aligned} & 25(4) \\
& 81(12) \\
& 147(21) \\
& 441(63)\end{aligned}$ & $\begin{array}{c}45(4) \\
141(13) \\
246(23) \\
636(60)\end{array}$ & $0.40^{\mathrm{a}}$ \\
\hline $\begin{array}{l}\text { ECOG PS, n (\%) } \\
0 \\
1 \\
2 \\
3 \\
4\end{array}$ & $\begin{array}{c}128(18) \\
302(44) \\
141(20) \\
110(16) \\
13(2)\end{array}$ & $\begin{array}{c}212(20) \\
479(45) \\
199(19) \\
164(15) \\
14(1)\end{array}$ & $0.70^{a}$ \\
\hline BMI, $\mathrm{kg} \mathrm{m}^{-2}$ & $22.3 \pm 3.0$ & $28.2 \pm 4.9$ & $<0.001^{b}$ \\
\hline TATI, $\mathrm{cm}^{2} \mathrm{~m}^{-2}$ & $61.0 \pm 37.8$ & $144.8 \pm 57.1$ & $<0.001^{b}$ \\
\hline SATI, $\mathrm{cm}^{2} \mathrm{~m}^{-2}$ & $30.4 \pm 12.6$ & $85.6 \pm 38.4$ & $<0.001^{b}$ \\
\hline VATI, $\mathrm{cm}^{2} \mathrm{~m}^{-2}$ & $30.6 \pm 29.0$ & $59.1 \pm 33.8$ & $<0.001^{b}$ \\
\hline SMI, $\mathrm{cm}^{2} \mathrm{~m}^{-2}$ & $45.8 \pm 8.6$ & $48.1 \pm 10$ & $<0.001^{b}$ \\
\hline $\begin{array}{l}\text { Muscle } \\
\text { radiodensity, HU }\end{array}$ & $38.7 \pm 8.4$ & $31.6 \pm 9.2$ & $<0.001^{b}$ \\
\hline \multicolumn{4}{|c|}{ 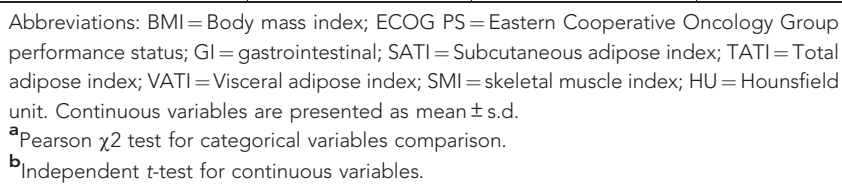 } \\
\hline
\end{tabular}

$(r=-0.43, P<0.001)$ and subcutaneous adiposity $(r=-0.44$, $P<0.001)$.

We did not include weight loss in our model, as the data were not available for metastatic renal cell carcinoma patients. However, in subgroup analysis of 1176 respiratory tract and colorectal cancer patients for whom weight loss was available, we observed that adiposity remained as an independent predictor of mortality in the presence of weight loss. Low adiposity independently associated with elevated mortality risk (HR: 1.18; 95\% CI: 1.01-1.37; $P=0.03)$ in a multivariate model adjusted for age, cancer type, stage, performance status, skeletal muscle index, muscle radiodensity and weight loss.

Presence of sarcopenia decreased the median survival within each 4 -adiposity phenotypes (Table 5). However, no significant difference in median survival was observed between sarcopenic and non-sarcopenic patients with concurrent high visceral and subcutaneous adiposity. The shortest median survival was observed in patients with a low VATI and SATI regardless of whether patients were sarcopenic or not. The effect of sarcopenia, however, was more pronounced in patients with low SATI. Therefore, in the presence of sarcopenia, the longest survival was observed in patients with high subcutaneous adiposity. 
Table 5. Effect of sarcopenia on median overall survival in high and low visceral and subcutaneous adiposity patients

\begin{tabular}{|c|c|c|c|c|}
\hline $\begin{array}{l}\text { 4-adiposity } \\
\text { phenotypes }\end{array}$ & SMI & $\begin{array}{l}\text { No. of } \\
\text { patients }\end{array}$ & $\begin{array}{l}\text { No. of } \\
\text { events }\end{array}$ & $\begin{array}{l}\text { Median survival, } \\
\text { months }(95 \% \mathrm{Cl})\end{array}$ \\
\hline & $\begin{array}{c}\text { Non- } \\
\text { sarcopenic }\end{array}$ & 359 & 232 & $21.8^{\mathrm{a}}(17-26.7)$ \\
\hline High SATI & Sarcopenic & 200 & 140 & $18.5^{\mathrm{a}, \mathrm{e}}(13.7-23.4)$ \\
\hline & $\begin{array}{c}\text { Non- } \\
\text { sarcopenic }\end{array}$ & 289 & 204 & $14.2^{\mathrm{b}}(11.3-17.1)$ \\
\hline Low SATI & Sarcopenic & 260 & 202 & $10.7^{c}(8.6-12.9)$ \\
\hline & $\begin{array}{c}\text { Non- } \\
\text { sarcopenic }\end{array}$ & 86 & 47 & $22.7^{a}(16-29.4)$ \\
\hline Low SATI & Sarcopenic & 51 & 36 & $12.8^{\mathrm{cd}}(5.7-20)$ \\
\hline Low VATI & $\begin{array}{c}\text { Non- } \\
\text { sarcopenic }\end{array}$ & 264 & 169 & $20.1^{\mathrm{a}}(17-23.2)$ \\
\hline High SATI & Sarcopenic & 235 & 161 & $16.4^{\mathrm{de}}(13.8-19)$ \\
\hline
\end{tabular}

Abbreviations: $\mathrm{Cl}=$ Confidence interval; SATI = Subcutaneous adipose index; $\mathrm{SMI}=$ skeletal muscle index; $V A T I=$ visceral adipose index. $V A T I \geqslant 52.9 \mathrm{~cm}^{2} \mathrm{~m}^{-2}$ in male and $\geqslant 51.5 \mathrm{~cm}^{2} \mathrm{~m}^{-2}$ in females were defined as high VATI. SATI $\geqslant 50 \mathrm{~cm}^{2} \mathrm{~m}^{-2}$ in males and $\geqslant 42 \mathrm{~cm}^{2} \mathrm{~m}^{-2}$ in females were defined as high SATI. Sarcopenia was defined using Martin et al established cut-offs in gastrointestinal and respiratory cancer patients (Martin et al, 2013) as values below $41 \mathrm{~cm}^{2} \mathrm{~m}^{-2}$ in females of all BMI categories and SMI values below $43 \mathrm{~cm}^{2} \mathrm{~m}^{-2}$ in male with a BMI $<25$ and $\mathrm{SMl}<53 \mathrm{~cm}^{2} \mathrm{~m}^{-2}$ in male with a BMl $\geqslant 25$. Different superscripts indicate significant differences $(P<0.05)$ determined by log-rank test. Median survival estimated using Kaplan-Meier method. HRs and $P$-values calculated using Cox proportional hazard model.

\section{DISCUSSION}

In this large, retrospective cohort study investigating the prognostic significance of adiposity in cancer mortality, low adiposity was as an independent predictor of mortality risk and shorter survival after adjusting for known prognostic variables including age, cancer type, stage, performance status, skeletal muscle index and muscle radiodensity. To our knowledge, this is the largest study assessing the association between adipose depots and cancer mortality. To determine whether different adipose depots, visceral or subcutaneous, associated with mortality risk in cancer patients, two different measures of adiposity, VATI and SATI were included in multivariate analysis. Our data demonstrate that cancer patients with lower subcutaneous adiposity are at greater risk of mortality and that patients with a high SATI experienced a significantly longer median survival time compared to those with a lower SATI. Moreover, having high VATI, without high subcutaneous adiposity increases mortality risk. This result is consistent with Antoun et al who reported that a high amount of subcutaneous adipose tissue independently and significantly associates with longer survival in 120 prostate cancer patients (Antoun et al, 2015). Controversy remains regarding the association between visceral adiposity and cancer survival as visceral adipose tissue is reported to be associated with poorer survival in patients with hepatocellular carcinoma (Fujiwara et al, 2015) or with better prognosis (Kaneko et al, 2015; Lee et al, 2015) in advanced renal cell carcinomas. Adiposity variables such as visceral to subcutaneous adipose tissue ratio have been applied in previous studies (Fujiwara et al, 2015).

Visceral and subcutaneous adipose tissue distribution differs between males and females. These depots are also metabolically different as visceral adipose tissue produces more inflammatory cytokines such as interleukin 6, tumour necrosis factor alpha and other adipokines (Fain et al, 2004; Harman-Boehm et al, 2007). Higher responsiveness of visceral adipose tissue to lipolytic factors as well as direct delivery of adipokines and free fatty acids to the liver links visceral adipose tissue to a pro-inflammatory state that can affect liver metabolism and whole body homeostasis (Girard and Lafontan, 2008). Subcutaneous adipose tissue, on the other hand, is the main producer of leptin (Ebadi et al, 2016) that exerts some metabolic benefits on insulin sensitivity, glucose and lipid metabolism (Tran et al, 2008; Porter et al, 2009). These metabolic differences demonstrate the necessity to evaluate cancer mortality based on visceral and subcutaneous adiposity rather than total adiposity.

Potential explanations for the protective effects of high adiposity have not been clearly identified. Excess adipose tissue in obese cancer patients may provide fuel to bridge the gap between decreased energy intake and elevated requirements as hypothesised by Hughes (2013). Obese patients may frequently undergo routine medical care and therefore be diagnosed at earlier stages (reviewed by Prado et al, 2015). Signals produced by adipose tissue, such as leptin, associates with better prognosis and longer survival in colorectal cancer patients (Ogino et al, 2009). Lower mRNA expression of fatty acid synthase and acetyl-CoA carboxylase, enzymes involved in fatty acid production as an energy substrate, have been observed in the tumour of obese renal cell carcinoma patients (Hakimi et al, 2013).

There was a moderate but highly significant inverse association between muscle radiodensity and adiposity in this study. Fat accumulation in the muscle (low muscle radiodensity) might be related to the various factors such as elevated transportation and uptake of fatty acid into muscle or increased availability of lipids (Miljkovic and Zmuda, 2010). On the other hand, enlarged fat mass associates with elevated release of fatty acids which might be considered as one of the potential sources contributing to the low muscle radiodensity (Boden, 2008). Although low adiposity and low muscle radiodensity were both independent predictors of mortality in this study, it may be appropriate to undertake further statistical analysis in order to assess the effect of various interactions between muscle radiodensity with adiposity on the survival of cancer patients.

We acknowledge various limitations of the present study. Although adiposity independently associates with mortality risk, the majority of patients were in Stage IV of their disease; therefore, results may not be generalised to the cancer patients in earlier stages of cancer. Lack of treatment data was also a limitation; however, data for all cancer types, except metastatic renal cell carcinoma patients, were collected during patients' first visit to medical oncology before undergoing any cancer treatment. Stage IV metastatic renal cell carcinoma patients are administrated sunitinib immediately after diagnosis, as part of standard care, and CTs for these patients were taken within a median of 26 days from the start of the treatment which is not a sufficient amount of time to change body composition from baseline. Lastly, the retrospective nature of this study limits assessment of various metabolic characteristics such as insulin resistance and inflammation in high and low adiposity patients.

In conclusion, lower adiposity independently associates with increased mortality risk after adjustment for major predictors of mortality in cancer patients. Among adipose tissue depots, subcutaneous adipose tissue appears to hold prognostic value over visceral adipose. When a combination of adiposity and sarcopenia was considered, presence of sarcopenia associated with shorter survival in all adiposity cancer patients. However, effect of sarcopenia on survival was more pronounced in patients with low subcutaneous adiposity. Therefore, high adiposity in the absence of sarcopenia appears to be a protective body composition phenotype, and associates with a survival advantage. Interventions to promote muscle anabolism and maintain adipose tissue should be considered in clinical settings to improve survival of cancer patients. 


\section{ACKNOWLEDGEMENTS}

We would like to thank Laura Birdsell, Rachel Murphy, Crystal Ginter, Nathalja C. Knijnenburg for image analysis. This study was supported by a grant from CIHR.

\section{CONFLICT OF INTEREST}

The authors declare no conflict of interest.

\section{AUTHOR CONTRIBUTIONS}

ME conducted data analysis and drafted the paper; SG was involved in data analysis; VCM assisted with the study conception, compilation of data and writing of manuscript; VEB assisted with the compilation and analysis of the data, revising the manuscript; CJF, RL and LM contributed to revising the manuscript. All authors have commented on the manuscript and approved the final version.

\section{REFERENCES}

Antoun S, Bayar A, Ileana E, Laplanche A, Fizazi K, di Palma M, Escudier B, Albiges L, Massard C, Loriot Y (2015) High subcutaneous adipose tissue predicts the prognosis in metastatic castration-resistant prostate cancer patients in post chemotherapy setting. Eur J Cancer 51: 2570-2577.

Aubrey J, Esfandiari N, Baracos VE, Buteau FA, Frenette J, Putman CT, Mazurak VC (2014) Measurement of skeletal muscle radiation attenuation and basis of its biological variation. Acta Physiol (Oxf) 210: 489-497.

Boden G (2008) Obesity and free fatty acids. Endocrinol Metab Clin North Am 37: 635-646viii-ix.

Dignam JJ, Polite BN, Yothers G, Raich P, Colangelo L, O'Connell MJ, Wolmark N (2006) Body mass index and outcomes in patients who receive adjuvant chemotherapy for colon cancer. J Natl Cancer Inst 98: $1647-1654$

Doria-Rose VP, Newcomb PA, Morimoto LM, Hampton JM, Trentham-Dietz A (2006) Body mass index and the risk of death following the diagnosis of colorectal cancer in postmenopausal women (United States). Cancer Causes Control 17: 63-70.

Ebadi M, Baracos VE, Bathe OF, Robinson LE, Mazurak VC (2016) Loss of visceral adipose tissue precedes subcutaneous adipose tissue and associates with n-6 fatty acid content. Clin Nutr 35: 1347-1353.

Ebadi M, Mazurak VC (2014) Evidence and mechanisms of fat depletion in cancer. Nutrients 6: 5280-5297.

Fabbro ED, Baracos V, Demark-Wahnefried W, Bowling T, Hopkinson J, Bruera E (eds) (2010) Nutrition and the Cancer Patient. Oxford University Press: New York, NY, USA.

Fain JN, Madan AK, Hiler ML, Cheema P, Bahouth SW (2004) Comparison of the release of adipokines by adipose tissue, adipose tissue matrix, and adipocytes from visceral and subcutaneous abdominal adipose tissues of obese humans. Endocrinology 145: 2273-2282.

Fujiwara N, Nakagawa H, Kudo Y, Tateishi R, Taguri M, Watadani T, Nakagomi R, Kondo M, Nakatsuka T, Minami T, Sato M, Uchino K, Enooku K, Kondo Y, Asaoka Y, Tanaka Y, Ohtomo K, Shiina S, Koike K (2015) Sarcopenia, intramuscular fat deposition, and visceral adiposity independently predict the outcomes of hepatocellular carcinoma. J Hepatol 63: 131-140.

Girard J, Lafontan M (2008) Impact of visceral adipose tissue on liver metabolism and insulin resistance. Part II: visceral adipose tissue production and liver metabolism. Diabetes Metab 34: 439-445.

Hakimi AA, Furberg H, Zabor EC, Jacobsen A, Schultz N, Ciriello G, Mikklineni N, Fiegoli B, Kim PH, Voss MH, Shen H, Laird PW, Sander C, Reuter VE, Motzer RJ, Hsieh JJ, Russo P (2013) An epidemiologic and genomic investigation into the obesity paradox in renal cell carcinoma. J Natl Cancer Inst 105: 1862-1870.

Harman-Boehm I, Bluher M, Redel H, Sion-Vardy N, Ovadia S, Avinoach E, Shai I, Kloting N, Stumvoll M, Bashan N, Rudich A (2007) Macrophage infiltration into omental versus subcutaneous fat across different populations: effect of regional adiposity and the comorbidities of obesity. J Clin Endocrinol Metab 92: 2240-2247.

Hughes V (2013) The big fat truth. Nature 497: 428-430.

Ibrahim MM (2010) Subcutaneous and visceral adipose tissue: structural and functional differences. Obes Rev 11: 11-18.

Kaneko G, Miyajima A, Yuge K, Yazawa S, Mizuno R, Kikuchi E, Jinzaki M, Oya M (2015) Visceral obesity is associated with better recurrence-free survival after curative surgery for Japanese patients with localized clear cell renal cell carcinoma. Jpn J Clin Oncol 45: 210-216.

Kasenda B, Bass A, Koeberle D, Pestalozzi B, Borner M, Herrmann R, Jost L, Lohri A, Hess V (2014) Survival in overweight patients with advanced pancreatic carcinoma: a multicentre cohort study. BMC Cancer 14: 728.

Kuk JL, Lee S, Heymsfield SB, Ross R (2005) Waist circumference and abdominal adipose tissue distribution: influence of age and sex. Am J Clin Nutr 81: 1330-1334.

Lee HW, Jeong BC, Seo SI, Jeon SS, Lee HM, Choi HY, Jeon HG (2015) Prognostic significance of visceral obesity in patients with advanced renal cell carcinoma undergoing nephrectomy. Int J Urol 22: 455-461.

Martin L, Birdsell L, Macdonald N, Reiman T, Clandinin MT, McCargar LJ, Murphy R, Ghosh S, Sawyer MB, Baracos VE (2013) Cancer cachexia in the age of obesity: skeletal muscle depletion is a powerful prognostic factor, independent of body mass index. J Clin Oncol 31: 1539-1547.

Meyerhardt JA, Catalano PJ, Haller DG, Mayer RJ, Benson 3rd AB, Macdonald JS, Fuchs CS (2003) Influence of body mass index on outcomes and treatment-related toxicity in patients with colon carcinoma. Cancer 98: 484-495.

Miljkovic I, Zmuda JM (2010) Epidemiology of myosteatosis. Curr Opin Clin Nutr Metab Care 13: 260-264.

Miller KD, Jones E, Yanovski JA, Shankar R, Feuerstein I, Falloon J (1998) Visceral abdominal-fat accumulation associated with use of indinavir. Lancet 351: 871-875.

Mitsiopoulos N, Baumgartner RN, Heymsfield SB, Lyons W, Gallagher D, Ross R (1998) Cadaver validation of skeletal muscle measurement by magnetic resonance imaging and computerized tomography. J Appl Physiol (1985) 85: 115-122.

Mourtzakis M, Prado CM, Lieffers JR, Reiman T, McCargar LJ, Baracos VE (2008) A practical and precise approach to quantification of body composition in cancer patients using computed tomography images acquired during routine care. Appl Physiol Nutr Metab 33: 997-1006.

Murphy RA, Wilke MS, Perrine M, Pawlowicz M, Mourtzakis M, Lieffers JR, Maneshgar M, Bruera E, Clandinin MT, Baracos VE, Mazurak VC (2010) Loss of adipose tissue and plasma phospholipids: relationship to survival in advanced cancer patients. Clin Nutr 29: 482-487.

Noori N, Kovesdy CP, Dukkipati R, Kim Y, Duong U, Bross R, Oreopoulos A, Luna A, Benner D, Kopple JD, Kalantar-Zadeh K (2010) Survival predictability of lean and fat mass in men and women undergoing maintenance hemodialysis. Am J Clin Nutr 92: 1060-1070.

Ogino S, Shima K, Baba Y, Nosho K, Irahara N, Kure S, Chen L, Toyoda S, Kirkner GJ, Wang YL, Giovannucci EL, Fuchs CS (2009) Colorectal cancer expression of peroxisome proliferator-activated receptor gamma (PPARG, PPARgamma) is associated with good prognosis. Gastroenterology 136: 1242-1250.

Porter SA, Massaro JM, Hoffmann U, Vasan RS, O’Donnel CJ, Fox CS (2009) Abdominal subcutaneous adipose tissue: a protective fat depot? Diabetes Care 32: 1068-1075.

Prado CM, Gonzalez MC, Heymsfield SB (2015) Body composition phenotypes and obesity paradox. Curr Opin Clin Nutr Metab Care 18: 535-551.

Rickles AS, Iannuzzi JC, Mironov O, Deeb AP, Sharma A, Fleming FJ, Monson JR (2013) Visceral obesity and colorectal cancer: are we missing the boat with BMI? J Gastrointest Surg 17: 133-143discussion p.143.

Schlesinger S, Siegert S, Koch M, Walter J, Heits N, Hinz S, Jacobs G, Hampe J, Schafmayer C, Nothlings U (2014) Postdiagnosis body mass index and risk of mortality in colorectal cancer survivors: a prospective study and meta-analysis. Cancer Causes Control 25: 1407-1418.

Shen W, Punyanitya M, Wang Z, Gallagher D, St-Onge MP, Albu J, Heymsfield SB, Heshka S (2004a) Total body skeletal muscle and adipose 
tissue volumes: estimation from a single abdominal cross-sectional image. J Appl Physiol (1985) 97: 2333-2338.

Shen W, Punyanitya M, Wang Z, Gallagher D, St-Onge MP, Albu J, Heymsfield SB, Heshka S (2004b) Visceral adipose tissue: relations between single-slice areas and total volume. Am J Clin Nutr 80: 271-278.

Tran TT, Yamamoto Y, Gesta S, Kahn CR (2008) Beneficial effects of subcutaneous fat transplantation on metabolism. Cell Metab 7: $410-420$.
Wajchenberg BL (2000) Subcutaneous and visceral adipose tissue: their relation to the metabolic syndrome. Endocr Rev 21: 697-738.

This work is published under the standard license to publish agreement. After 12 months the work will become freely available and the license terms will switch to a Creative Commons AttributionNonCommercial-Share Alike 4.0 Unported License.

Supplementary Information accompanies this paper on British Journal of Cancer website (http://www.nature.com/bjc) 